\title{
Acromegaly and the thyroid gland
}

Andrzej Lewiński, $\stackrel{\text { Affl Aff2 }}{\text { Coff }}$

Corresponding Affiliation: Aff1

Magdalena Marcinkowska, $\stackrel{\text { Aff2 }}{2}$

ArticleInfo

\begin{tabular}{|c|c|c|}
\hline ArticleID & $:$ & 208 \\
\hline ArticleDOI & : & 10.1186/1756-6614-8-S1-A20 \\
\hline ArticleCitationID & $:$ & A 20 \\
\hline ArticleSequenceNumber & $:$ & 20 \\
\hline ArticleCategory & $:$ & Meeting abstract \\
\hline ArticleFirstPage & $:$ & 1 \\
\hline ArticleLastPage & $:$ & 4 \\
\hline ArticleHistory & : & $\begin{array}{ll}\text { RegistrationDate } & : 2015-6-22 \\
\text { OnlineDate } & : 2015-6-22\end{array}$ \\
\hline ArticleCopyright & $:$ & $\begin{array}{l}\text { Lewiński and Marcinkowska; licensee BioMed Central } \\
\text { Ltd.2015 } \\
\text { This article is published under license to BioMed Central } \\
\text { Ltd. This is an Open Access article distributed under the } \\
\text { terms of the Creative Commons Attribution License } \\
\text { (http://creativecommons.org/licenses/by/4.0), which permits } \\
\text { unrestricted use, distribution, and reproduction in any } \\
\text { medium, provided the original work is properly cited. The } \\
\text { Creative Commons Public Domain Dedication waiver } \\
\text { (http://creativecommons.org/publicdomain/zero/1.0/) applies } \\
\text { to the data made available in this article, unless otherwise } \\
\text { stated. }\end{array}$ \\
\hline
\end{tabular}

Aff1

Department of Endocrinology and Metabolic Diseases, Medical University of Lodz, Lodz, Poland Aff2

Department of Endocrinology and Metabolic Diseases, Polish Mother's Memorial Hospital - Research Institute, Lodz, Poland

Spring School of Thyroidology organized by the Polish Thyroid Association 2014: abstracts of invited lectures

Spring School of Thyroidology organized by the Polish Thyroid Association 2014

Miedzyzdroje, Poland

23-24 May 2014

Publication of this supplement was funded by the Polish Thyroid Association. The Supplement Editors declare that they have no competing interests. 
Acromegaly is a chronic disease caused by hypersecretion of growth hormone (GH), most frequently from a pituitary somatotropic adenoma. Its prevalence was estimated at 60-70 cases per million people, but in recent years it seems to be higher (even 86 cases per million). Approximately 3-4 new cases of acromegaly are annually diagnosed per million people.

In acromegalic patients, the mortality rate is $2-4$ times higher than in the general population. The most common causes of death in patients in question are cardiovascular and/or respiratory complications, or neoplastic diseases.

Data indicating the increased risk of the development of benign and malignant tumors of various organs, particularly of the colon, thyroid gland, breast, and prostate, are reported in numerous studies. An elevated level of IGF-I seems to be responsible for the increased risk of cancers. It is to be recalled that IGF-I is a mitogenic, anti-apoptotic and angiogenesis-promoting factor.

Prevalence of cancers in acromegalic patients remains controversial: some authors describe the increased prevalence, in contrast, others do not. The difference among studies may be due to a low incidence of acromegaly per se, retrospective nature of studies or to differences in study designs. In most studies, patients with cancers diagnosed prior to acromegaly were excluded [1].

The presence of IGF-I receptors was shown in both normal and neoplastic thyroid tissue in humans, a long time ago. There are numerous scientific evidence that IGF-I reveals an important, TSH-independent effect in growth processes in humans thyroid $[\underline{2}, \underline{3}]$. Moreover, there are a lot of studies describing the increased prevalence of goitre (both diffuse and nodular) in acromegalic patients, and many authors have demonstrated a positive correlation between the thyroid volume and serum IGF-I concentration.

Large meta-analysis published recently by Wolinski et al. [4] has confirmed that both thyroid nodular disease and thyroid carcinoma are significantly more frequent in acromegalic patients than in general population (Table 1 ).

Table 1 Studies with control group included in meta-analysis - the table taken from the study by Wolinski et al. [4], modified. Asterisk (*) - persons with non-functioning or Prl secreting adenomas.

\begin{tabular}{|l|l|l|l|l|l|}
\hline Studies with control group & $\begin{array}{l}\text { Acromegali } \\
\text { c patients }\end{array}$ & $\begin{array}{l}\text { Cases of thyroid } \\
\text { carcinoma in } \\
\text { group } \\
\text { acromegalic of } \\
\text { patients }\end{array}$ & $\begin{array}{l}\text { Control } \\
\text { group } \\
\text { thyroid } \\
\text { carcinoma in } \\
\text { control } \\
\text { group }\end{array}$ & \\
\hline $\begin{array}{l}\text { dos Santos et al., Pituitary } \\
\text { 2013;16:109-114 }\end{array}$ & 124 & $9(7.25 \%)$ & $\begin{array}{l}263 \quad \text { (not } \\
\text { specified) }\end{array}$ & $2(0.76 \%)$ & $9.5(2.2-48.0)$ \\
\hline $\begin{array}{l}\text { Herrmann et al., Clin Endocrinol } \\
\text { Diabet. } \\
\text { retrospective 2004;112:225-230; }\end{array}$ & 73 & $4(5.5 \%)$ & $\begin{array}{l}199 \\
\text { (healthy } \\
\text { volunteers) }\end{array}$ & 0 & $25.8(1.4-486.0)$ \\
\hline $\begin{array}{l}\text { Gasperi et al., J Endocrinol Invest. } \\
2002 ; 25: 240-245\end{array}$ & 258 & $3(1.16 \%)$ & $150^{*}$ & $1(0.66 \%)$ & $1.7(0.2-16.9)$ \\
\hline $\begin{array}{l}\text { Popovic et al. Clin Endocrinol (Oxf) } \\
1998 ; 49: 441-445 ; \text { retrospective }\end{array}$ & 220 & $3(1.36 \%)$ & $248^{*}$ & 0 & $8.0(0.4-155.7)$ \\
\hline $\begin{array}{l}\text { Barzilay et al., Arch Intern Med. } \\
1991 ; 151: 1629-1632 ; \text { retrospective }\end{array}$ & 87 & $2(2.3 \%)$ & $198^{*}$ & 0 & $11.6(0.6-244.4)$ \\
\hline
\end{tabular}


Accordingly, these results demonstrate that the repeated thyroid ultrasound (US) examination and careful evaluation of possible lesions (together with cytological assessment) should be important part of follow-up in patients with acromegaly. Wolinski et al. [4] documented that in newer studies on acromegalic subjects, thyroid disorders were reported more frequently - in studies published after year 2008, thyroid nodular disease occurred in about $65 \%$ of patients whereas in older studies approx. in $54 \%$. Similar phenomenon could be recorded in case of thyroid carcinomas $-6 \%$ patients in newer reports published after 2008 vs. 3\% in older studies, published before 2008. These results speak for the hypothesis that the improvement in diagnostic methods and therapy of acromegaly extends the survival time of patients, what - in turn - increases the prevalence of benign and malignant neoplasms possible to detect.

Result of selected studies on acromegaly and thyroid disorders, published in recent years, are presented in Tables $\underline{2}$ and $\underline{3}$.

Table 2 Results of the retrospective study by Turkish authors [1], including 64 acromegalic patients who were subjected to thyroid US examination and thyroid function tests (distribution of thyroid diagnoses).

\begin{tabular}{|l|l|l|l|l|l|l|}
\hline Multinodular goitre & $\begin{array}{l}\text { Simple } \\
\text { nodule }\end{array}$ & $\begin{array}{l}\text { Toxic multinodular } \\
\text { goitre }\end{array}$ & $\begin{array}{l}\text { Hürthle cell } \\
\text { adenoma }\end{array}$ & $\begin{array}{l}\text { Diffuse } \\
\text { goitre }\end{array}$ & $\begin{array}{l}\text { Thyroid } \\
\text { carcinoma }\end{array}$ & $\begin{array}{l}\text { No thyroid } \\
\text { disease }\end{array}$ \\
\hline $31(48.4 \%)$ & $6(9.4 \%)$ & $1(1.6 \%)$ & $1(1.6 \%)$ & $9(14.1 \%)$ & $5(7.8 \%)$ & $11(17.1 \%)$ \\
\hline
\end{tabular}

Table 3 Results of study from Brasil, including 106 acromegalic patients, who were subjected to thyroid US examination [5]. In 4 patients (3.8\%) thyroid carcinoma was diagnosed in cytological examination (2 cases multifocal papillary thyroid carcinoma, 1 - papillary microcarcinoma, 1 - papillary variant of follicular thyroid carcinoma).

\begin{tabular}{|l|l|l|l|l|}
\hline Multinodular goitre & Simple nodule & $\begin{array}{l}\text { Unspecific abnormalities (colloid cyst or } \\
\text { heterogenous texture) }\end{array}$ & Normal US goitre \\
\hline $34(32.5 \%)$ & $8(7.5 \%)$ & $22(20.6 \%)$ & $11(10.4 \%)$ & $31(29 \%)$ \\
\hline
\end{tabular}

\section{References}

1. Dogan S, Atmaca A, Dagdelen S, Erbas B, Erbas T: Evaluation of thyroid diseases and differentiated thyroid cancer in acromegalic patients. Endocrine 2014,45(1):114-121. 10.1007/s12020-013-9981-3

2. Lewiński A, Marcinkowska M, Brzeziańska E, Tantush AS, Włoch J, Brzeziński J: Effect of exogenous insulin-like growth factor-I (IGF-I) on the expression of the IGF-I gene and the genes of IGF-binding proteins (IGFBPs) 1-4 in human thyroid cells from nodular goiter, follicular adenoma and follicular carcinoma cultured in monolayers. J Endocr Genet 2003,3(3-4):141-149.

3. Lewiński A, Marcinkowska M, Brzeziańska E, Jeziorowska A, Włoch J, Brzeziński J: Expression of insulin-like growth factor I (IGF-I) gene and of genes for IGF-binding proteins 1, 2, 3, 4 (IGFBP-1-IGFBP-4) in non-neoplastic human thyroid cells and in certain human thyroid cancers. Effect of exogenous IGF-I on this expression. Endocrine Res 2004,30(1):47-59. 10.1081/ERC-120028484

4. Wolinski K, Czarnywojtek A, Ruchala M: Risk of thyroid nodular disease and thyroid cancer in patients with acromegaly - meta-analysis and systematic review. PLoS One 2014,9(2):e88787. 10.1371/journal.pone.0088787 
5. Uchoa HB, Lima GA, Corrêa LL, Vidal AP, Cavallieri SA, Vaisman M, Buescu A, Gadelha MR: Prevalence of thyroid diseases in patients with acromegaly: experience of a Brazilian center. Arq Brasil Endocrinol Metab 2013,57(9):685-690. 10.1590/S0004-27302013000900003 